\title{
Hubungan Nyeri Punggung Bawah Dengan Duduk Lama: Sebuah Tinjauan Literatur Naratif
}

\author{
Aurelio Chandra ${ }^{1}$, Lichita Indra ${ }^{1}$ \\ ${ }^{1,1)}$ Program Studi Ilmu Kesehatan Masyarakat, Fakultas Kesehatan Masyarakat, \\ Universitas Indonesia \\ Kampus Universitas Indonesia, Depok, 16424 \\ Email: aurelio.chandra@ui.ac.id, lichita.indra@ui.ac.id
}

\begin{abstract}
ABSTRAK
Nyeri punggung bawah merupakan salah satu keluhan kesehatan yamg paling sering dilaporkan di dunia. Diyakini bahwa hampir semua orang akan mengalami keluhan ini pada satu saat dalam hidupnya. Hingga saat ini, telah banyak penelitian dilakukan di berbagai negara untuk mengetahui penyebab dan faktor-faktor risiko dari kejadian nyeri punggung bawah. Meskipun upaya terbaik telah dilakukan melalui penelitian dengan berbagai desain studi, penyebab nyeri punggung bawah masih menjadi polemik. Salah satu hal yang masih diperdebatkan untuk menjadi penyebab nyeri punggung bawah adalah duduk lama. Duduk lama diartikan sebagai aktivitas duduk dalam waktu yang lama hingga berjam-jam, baik saat bekerja ataupun bersantai. Tinjauan literatur naratif ini dilakukan untuk mengetahui hubungan duduk lama dengan nyeri punggung bawah melalui peninjauan kembali terhadap penelitian-penelitian terdahulu. Pencarian literatur dilakukan melalui penelusuran database SCOPUS untuk mencari studi berbahasa Inggris dengan kata kunci low back pain dan prolonged sitting time, dari tahun 2014 hingga 2020. Hasil tinjauan literatur ini menemukan bahwa duduk lama belum dapat dikatakan dengan pasti memiliki hubungan kausal dengan nyeri punggung bawah. Hal ini dikarenakan nyeri punggung bawah merupakan kejadian yang multifaktorial dan durasi duduk yang lama saja tidak dapat menimbulkan keluhan ini. Kendati demikian, duduk lama yang disertai dengan perilaku duduk statis disinyalir dapat menjadi penyebab peningkatan risiko kejadian nyeri punggung bawah.
\end{abstract}

Kata kunci: nyeri punggung bawah, duduk lama, waktu duduk, tinjauan literatur naratif

\begin{abstract}
Low back pain is one of the most common health problems reported globally. It is said that almost all people in the world might suffer this pain in some point of their lives. A lot of studies have been conducted in various countries to find the cause and risk factors of low back pain. Despite all the best efforts through a lot of researches and studies with variety of designs, the cause of low back pain is still a polemic. One of the factors that being discussed as the potential cause of low back pain is prolonged sitting. Prolonged sitting is defined as sitting activity in a long time, usually until hours, at work as well as at leisure time. This narrative literature review aims to know the association between prolonged sitting and low back pain through review of previous researches and studies. The literature was searched through SCOPUS database to find newest studies in English language with keyword "low back pain" and "prolonged sitting time" from 2014 to 2020. Results from this literature review showed that prolonged sitting still cannot be determined to have causal relationship with low back pain. This finding might be due to the nature of low back pain as a multifactorial occurrence. Therefore, prolonged sitting duration alone cannot cause low back pain. Nevertheless, prolonged sitting followed by static sitting behavior are presumably the cause of increased risk of low back pain incident.
\end{abstract}

Keywords: low back pain, prolonged sitting, sitting time, narrative literature review

\section{Pendahuluan}

Nyeri punggung bawah atau low back pain merupakan salah satu keluhan sakit yang paling sering dilaporkan kedua di dunia setelah sakit kepala dan menempati posisi pertama dalam YLD (Years Lived with Disability) $(1,2)$. Prevalensi kejadian nyeri punggung bawah semasa hidup diperkirakan mencapai sebesar $84 \%$, bergantung kepada definisi penyakit dan kasus yang dialami, namun tidak terbatas pada kelompok umur tertentu, bahkan pada anakanak (3). Kendati demikian, kejadian nyeri punggung bawah ini lebih banyak dialami oleh orang dewasa karena berbagai faktor risiko okupasional yang terasosiasikan dengan keluhan ini (3). Beberapa faktor risiko okupasional yang sering diasosiasikan memiliki hubungan positif dengan kejadian nyeri punggung adalah penanganan material manual dan duduk lama saat bekerja (3). 
Secara umum, orang dewasa dapat menghabiskan sebanyak 6-8 jam atau lebih adari 45-50\% waktu terjaga mereka dalam posisi duduk, terutama ketika bekerja (4-8). Hal ini menjadikan mereka memiliki gaya hidup sedenter, yang merupakan gaya hidup dengan pengeluaran energi hanya sebesar 600 MET menit per minggu dan didominasi dengan duduk lama saat kerja ataupun saat waktu bersantai (9). Studi menemukan bahwa gaya hidup sedenter memiliki pengaruh signifikan dalam kejadian nyeri punggung bawah berulang (10). Penelitian terdahulu telah banyak mengaitkan duduk lama mungkin menjadi faktor risiko terjadinya nyeri punggung bawah $(11,12)$. Mekanisme yang mungkin menjadi faktor penyebab dalam hubungan nyeri punggung bawah dan duduk lama adalah peningkatan tekanan intradiscal (13), kekauan lumbal tulang belakang (14), dan penurunan kekuatan otot punggung bawah $(14,15)$.

Studi oleh Omokhodion dan Sanya (16) menemukan bahwa waktu duduk yang lama saat kerja (misalnya 3 jam atau lebih) dapat meningkatkan peluang terjadinya nyeri punggung bawah. Penemuan ini sejalan dengan penemuan dalam studi potong lintang dan studi prospektif lainnya mengenai hubungan antara nyeri punggung bawah dengan duduk lama (16-24). Hal ini dapat terjadi karena dalam perilaku duduk hingga waktu yang lama atau berjam-jam biasanya diikuti oleh perilaku duduk yang statis sehingga meningkatan risiko terjadinya gangguan muskuloskeletal pada punggung $(25,26)$.

Akan tetapi, beberapa studi (27-30) gagal menemukan bukti hubungan sebab-akibat antara nyeri punggung bawah dengan duduk lama, sehingga dikonklusikan bahwa gaya hidup sedenter saja tidak dapat meningkatkan kejadian nyeri punggung bawah. Meskipun demikian, terdapat satu penelitian yang dilakukan oleh Lis, dkk pada tahun 2007 mengusulkan bahwa duduk lama dengan posisi duduk yang kaku dan statis dapat meningkatkan peluang terjadinya nyeri punggung bawah (30).

Tinjauan literatur ini bertujuan untuk mengetahui lebih lanjut mengenai hubungan antara duduk lama dengan kejadian nyeri punggung bawah melalui tinjauan terhadap studi dan penelitian terdahulu. Tinjauan ini diharapkan dapat memberikan gambaran mengenai hubungan antara nyeri punggung bawah dengan duduk lama. Duduk lama yang disertai dengan perilaku duduk statis disinyalir menjadi salah satu faktor risiko yang dapat meningkatkan terjadinya nyeri punggung bawah.

\section{Metode Penelitian}

Penelitian ini merupakan studi tinjauan literatur yang dilakukan dengan cara meninjau penelitian potong lintang dan prospektif yang telah ada. Penelusuran literatur dilakukan melalui pencarian pada database SCOPUS dengan kata kunci low back pain dan prolonged sitting time. Artikel-artikel yang dipilih merupakan artikel berbahasa Inggris yang memiliki status akses terbuka (open access) dari tahun 2014 hingga 2020. Penelusuran lebih lanjut terhadap studi lainnya dilakukan dengan pemeriksaan terhadap daftar Pustaka atau referensi dari artikel-artikel yang telah dipilih.

\section{Hasil dan Pembahasan}

\section{Hasil Penelusuran Literatur}

Hasil pencarian literatur melalui database SCOPUS berhasil menemukan sebanyak 83 artikel dalam berbagai bahasa dalam rentang tahun 1992 hingga 2020 dengan status akses terbuka maupun tertutup. Dari 83 artikel tersebut dilakukan pemilihan artikel untuk mendapatkan artikel yang relevan dengan tujuan tinjauan literatur, memiliki akses terbuka, dan berbahasa Inggris, serta dalam rentang waktu 2014 hingga 2020. Terdapat 12 artikel yang dipilih yang mana sepuluh artikel merupakan hasil studi potong lintang dan studi prospektif. Dari sepuluh studi tersebut, terdapat studi yang bersifat objektif, subjektif, dan juga perpaduan antara studi subjektif dan objektif yang akan dibahas satu per satu dalam tinjauan ini. Sedangkan dua artikel lainnya merupakan tinjauan literatur sistematik yang akan digunakan sebagai acuan dalam membentuk struktur tinjauan literatur ini.

Dua dari sepuluh studi yang terpilih merupakan penelitian terhadap buruh, tiga studi dengan sampel pekerja kantor, dua studi terhadap populasi universitas yaitu satu studi terhadap mahasiswa dan satu studi terhadap pekerja akademik dan non-akademik di universitas. Tiga studi lainnya memiliki sampel perawat dan paramedik di rumah sakit, pasien klinik neurologi di salah satu rumah sakit di Indonesia dan yang terakhir dengan sampel orang tidak memiliki gejala nyeri punggung bawah dan orang yang memiliki gejala nyeri punggung bawah yang dapat diperparah atau disebabkan oleh duduk. Hanya satu studi yang menemukan bahwa waktu duduk yang lebih lama merupakan faktor protektif bagi pekerja kerah biru atau buruh dari kejadian nyeri punggung bawah. Sedangkan studi lainnya sebagian besar menemukan bahwa duduk lama dan perilaku duduk statis dapat memicu kejadian nyeri punggung bawah secara umum, tanpa terbatas usia maupun jenis kelamin.

\section{Faktor Risiko Duduk Lama}


Artikel oleh Gupta dkk (31) memiliki tujuan untuk menginvestigasi hubungan antara waktu duduk yang dihitung secara objektif (total waktu duduk per-hari, waktu duduk saat jam kerja, dan waktu duduk saat istirahat) dengan nyeri punggung bawah pada pekerja kerah biru (buruh). Penelitian dilakukan di Denmark dan menggunakan desain studi cross-sectional berhasil mengumpulkan sebanyak 201 pekerja kerah biru (buruh) dari tempat kerja yang berbeda (konstruksi, pembersih, pemulung, pekerja manufaktor, perakit, operator alat berat, dan tenaga kesehatan) dengan status sosioekonomi yang relatif homogen. Pekerja tersebut dipasangkan dengan dua accelerometer (GT3X + Actigraph) selama 4 hari kerja untuk mendapatkan waktu duduk yang objektif, diestimasi dengan menggunakan perangkat lunak Acti4. Pekerja lalu melaporkan intensitas nyeri tulang punggung bawah mereka sebulan terakhir dengan skala 0 (tidak nyeri) sampai 9 (sangat sakit) dan dikategorikan sebagai nyeri punggung bawah rendah $(<=5)$ dan nyeri punggung bawah tinggi $(>=5)$. Dalam regresi logistik multivariat, total waktu duduk, waktu duduk saat jam kerja dan waktu duduk saat istirahat dibuat kedalam model sebagai variabel continuous (jam/hari) dan kategoris (waktu duduk rendah, sedang, tinggi). Penelitian menunjukan hasil yang signifikan berorientasi positif antara lama waktu duduk dengan intensitas nyeri punggung bawah (OR: 1.43, 95\% $\mathrm{CI}=1.15-1.77, \mathrm{P}=0.01)$. Hasil yang sama juga didapatkan untuk waktu duduk saat istirahat $(\mathrm{OR}=1.45$, 95\% CI=1.10-1.91, $\mathrm{P}=0.01$ ), dan hasil tren yang sama namun tidak signifikan untuk waktu duduk saat kerja $(\mathrm{OR}=1.34$, 95\%CI 0.99-1.82, $\mathrm{P}=0.06)$. Analisis pada kategori waktu duduk, waktu duduk tinggi/lama berhubungan positif dengan nyeri punggung bawah yang tinggi $(\mathrm{OR}=3.31,95 \% \mathrm{CI}=1.18-9.28, \mathrm{P}=0.03)$ untuk total waktu duduk per hari, $(\mathrm{OR}=5.31,95 \% \mathrm{CI}=1.57-17.90, \mathrm{P}=0.01)$ untuk waktu duduk saat istirahat, dan $(\mathrm{OR}=3.26$, 95\% CI=0.89-11.98, $\mathrm{P}=0.08$ ) untuk waktu duduk saat kerja. Penelitian yang dilakukan oleh Gupta dkk (31) menyimpulkan bahwa waktu duduk berhubungan positif dengan intensitas nyeri punggung bawah diantara pekerja kerah biru.

Penelitian yang dilakukan oleh Nordin dkk (32) memiliki tujuan untuk mengidentifikasi faktor risiko yang berhubungan sebagai penyebab nyeri punggung bawah diantara mahasiswa kesehatan. Penelitian dilakukan di Malaysia dengan menggunakan desain studi survei cross-sectional dan berhasil mendapatkan seratus empat puluh empat responden mahasiswa kesehatan yang aktif berkuliah di Universitas Kebangsaan Malaysia. Responden berumur antara 18-22 tahun dengan mayoritas responden didominasi perempuan (70\%), 60\% diantaranya merupakan mahasiswa tingkat tiga. Responden lalu diberikan kuesioner yang sama dengan penelitian Nyland dkk (33) tanpa perubahan dan responden tidak akan diikutsertakan apabila responden memiliki kelainan tulang belakang seperti skoliosis, spondylolisthesis, spondylosis, spondylolisis, spinal stenosis, prolapses intervertebral disc dan kelainan neurologis serta riwayat nyeri punggung bawah selama 6 bulan terakhir sebelum diikutsertakan ke dalam penelitian. Kuesioner terdiri dari 3 bagian yaitu demografi responden, detil riwayat nyeri punggung bawah semenjak kuliah di fakultas dan data mengenai faktor risiko seperti tingkat kebugaran self-rated, lama waktu duduk, dan lama waktu untuk berolahraga. Data diolah menggunakan SPSS software version 16 dan tes Chi square digunakan untuk mengetahui hubungan faktor risiko dengan nyeri punggung bawah, test dengan $\mathrm{p}<0.05$ dianggap signifikan. Hasil penelitian menunjukan bahwa nyeri punggung bawah berhubungan dengan umur $\left(\mathrm{X}^{\wedge} 2=12.1, \mathrm{p}=0.007\right)$, lama studi $\left(\mathrm{X}^{\wedge} 2=8.7, \mathrm{p}=0.03\right)$, tingkat kebugaran yang dinilai sendiri $\left(\mathrm{X}^{\wedge} 2=7.0\right.$, $\mathrm{p}=0.02)$, dan lama waktu duduk $\left(\mathrm{X}^{\wedge} 2=8.7, \mathrm{p}=0.03\right)$. Jenis kelamin, IMT, dan lama waktu olahraga tidak memiliki hubungan dengan nyeri punggung bawah. Kesimpulan yang diambil Nordin dkk adalah tingkat kebugaran dan lama waktu duduk berhubungan dengan kejadian nyeri punggung bawah diantara mahasiswa kesehatan sehingga dianjurkan untuk membiasakan diri melakukan stretching saat duduk, istirahat sejenak, dan meningkatkan kebugaran tubuh.

Penelitian lain terhadap pekerja kerah biru atau buruh yang dilakukan oleh Korshoj, dkk (47) pada tahun 2018, menyatakan bahwa duduk merupakan faktor protektif bagi populasi ini. Studi ini merupakan studi prospektif yang dilakukan di Denmark yang berdasarkan Danish Physical Activity Cohort with Objective measurements (DPHACTO) terhadap 665 pekerja kerah biru dari 15 perusahaan di bidang pembersihan, transportasi dan manufaktur. Waktu duduk saat kerja diukur menggunakan accelerometry dan dinyatakan dalam bentuk durasi total dan pola temporal duduk dengan kategori [persentase waktu kerja untuk istirahat singkat ( $\leq 5$ menit), sedang (>5 - $\leq 20$ menit) dan periode lama dengan waktu lebih dari 20 menit]. Time course dari nyeri punggung bawah (skala 0-10) dikumpulkan setiap bulan selama satu tahun melalui pesan singkat. Studi menyimpulkan bahwa periode durasi duduk total dan temporal saat kerja berasosiasi secara signifikan dengan perjalanan waktu yang menguntungkan dari nyeri punggung bawah. Peningkatan durasi duduk sebanyak lima menit saat bekerja akan sesuai dengan penurunan dalam satu tahun perjalanan dari nyeri punggung bawah sebanyak -0.05 points. Hal ini mungkin terjadi karena para pekerja kerah biru tidak terpapar tugas kerja lainnya yang berbahaya dan berisiko terhadap nyeri punggung bawah, seperti mengangkat barang atau manual material handling, dan waktu duduk digunakan untuk memulihkan diri dari tugas kerja yang berbahaya tersebut (48). Hasil dari penelitian ini bertentangan dengan hasil penelitian sebelumnya oleh Gupta dkk (31) yang pada tahun 2015 menyatakan bahwa waktu duduk berpengaruh positif terhadap kejadian nyeri punggung bawah pada pekerja kerah biru.

Studi yang dilakukan oleh Waongengarm dkk (43) dilakukan terhadap 40 pekerja kantor di Thailand dan bertujuan untuk menguji hubungan antara ketidaknyamanan yang dirasakan dengan pergantian atau pergeseran postural ketika duduk saat bekerja selama empat jam. Partisipan merupakan pekerja kantor berusia 20-45 tahun yang 
memiliki setidaknya lima tahun pengalaman kerja dan bisa menggunakan komputer serta tidak memiliki keluhan nyeri punggung bawah dan leher pada minggu terakhir, tidak memiliki nyeri leher dan punggung bawah yang kronis, serta tidak memiliki tanda-tanda defisit neural, dan gangguan sendi ataupun luka lainnya pada bagian punggung bawah. Partisipan diminta untuk mengetik tulisan di komputer selama empat jam dan diperbolehkan untuk melakukan pergerakan atau pergeseran postural dimana pergeseran postural ini diukur dari analisis indeks dispersi dari kedua ischial tuberosities berdasarkan data tekanan duduk dari pressure mat. Ambang batas pergeseran postural ditetapkan kurang lebih $10 \%$ dan $20 \%$. Hasil penelitian menujukkan bahwa terjadi peningkatan ketidaknyamanan yang dirasakan secara terus menerus dalam waktu empat jam duduk tersebut. Bagian tubuh yang dirasa paling tidak nyaman adalah punggung bagian bawah, punggung bagian atas, paha, dan leher. Dikonklusikan bahwa duduk lama meningkatkan rasa ketidaknyamanan muskuloskeletal dan jumlah pergeseran postural pada kedua magnitudo (10\% dan 20\%) meningkat pada dua jam pertama dan pada dua jam terakhir hanya jumlah pergeseran postural pada ambang 20\% yang meningkat. Dapat dipahami bahwa ketidaknyamanan yang dirasakan ketika duduk terlalu lama akan memicu seseorang untuk melakukan pergerakan atau pergeseran postural yang lebih besar (di ambang 20\%), karena duduk terlalu lama memicu aktivasi otot leher dan punggung $(44,45)$. Kontraksi statis otot pada level submaksimal ini dapat memicu tekanan otot terlokalisasi, kelelahan otot, dan ketegangan otot yang memicu rasa tidak nyaman dan sakit (46). Hasil studi ini menyarankan bahwa durasi duduk selama 30-80 menit dapat meningkatkan risiko nyeri punggung bawah dan nyeri pada leher.

Studi lainnya merupakan studi mengenai faktor risiko kejadian nyeri sendi sakroiliaka terhadap pasien di klinik neurologi salah satu rumah sakit di Indonesia. Sakit sendi sakroiliaka merupakan salah satu penyebab terbesar nyeri punggung bawah dengan sumber mekanik, terlepas dari apapun jenis kelamin penderitanya, dengan prevalensi 15-38\% dari 13\% nyeri punggung bawah yang berkepanjangan (49-51). Studi ini merupakan penelitian prospektif yang dilakukan oleh Siahaan dan Hartoyo (52) terhadap 99 pasien di klinik rawat jalan neurologi Rumah Sakit Siloam Lippo Village, Tangerang, Indonesia dengan usia pasien 17-75 tahun. Pasien yang memiliki riwayat autoimun dan berbagai kelainan di bagian pelvis berdasarkan hasil skrining radiologi tidak diperbolehkan untuk berpartisipasi dalam penelitian ini. Pasien yang menjadi partisipan dievaluasi terkait faktor-faktor predisosisi mereka, skala sakit, dan pemeriksaan neurologis. Diagnosis sakit atau nyeri sendi sakroiliaka ditegakkan dengan menggunakan blok anestesi dan melakukan observasi terhdap penurunan rasa sakit yang melebihi 75\%. Skala rasa sakit dievaluasi 15 menit setelah injeksi anestesi dilakukan dan hasil dinyatakan positif jika ada penurunan rasa sakit minimal $75 \%$. Studi ini menemukan bahwa faktor-faktor yang dapat memicu nyeri sendi sakroiliaka adalah jenis kelamin perempuan, berusia 40-59 tahun, riwayat kehamilan ganda, duduk selama 6 jam lebih ketika terjaga, dan bekerja di kantor. Hasil dari penelitian ini sejalan dan mendukung hasil penelitian dari Gupta dkk pada tahun 2015 yang menyatakan bahwa lama waktu duduk memiliki hubungan positif dengan kejadian nyeri punggung bawah (31).

\section{Faktor Risiko Posisi Duduk}

Artikel oleh Bontrup dkk (34) merupakan hasil penelitian yang memiliki tujuan untuk mengetahui hubungan antara nyeri punggung bawah dengan kebiasaan duduk saat jam kerja pada 64 karyawan call-center. Penelitian dilakukan di perusahaan call-center yang berlokasi di Dresden dan Leipzig, Jerman dengan menggunakan desain studi prospektif di mana penelitian ini dilaksanakan selama 2 minggu di 2 tempat kerja yang berbeda di masingmasing perusahaan. Masing-masing partisipan akan dipasangkan dengan alat monitoring posisi duduk dan dibiarkan bekerja seperti biasanya, partisipan juga dimintai tolong untuk duduk empat kali dalam tujuh posisi duduk yang berbeda: tegak, menyender, condong ke depan, miring ke kiri/kanan, kaki menyilang kaki kiri ke kanan/ kanan ke kiri. Setelah selesai partisipan akan diminta untuk mengisi kuesioner yang berisi pertanyaan mengenai informasi sosiodemografi, dan nyeri punggung bawah. Partisipan ditolak apabila partisipan sedang hamil, mengkonsumsi glukokortikoid, atau sedang menjalani perawatan medis. Data diolah menggunakan perangkat lunak SPSS versi 24. Penelitian menunjukan bahwa individu dengan nyeri punggung bawah kronis kemungkinan cenderung (t-test tidak signifikan) memiliki kebiasaan duduk statis dibandingkan dengan individu yang tidak memiliki nyeri punggung bawah kronis, selanjutnya hubungan erat terlihat diantara kebiasaan duduk dengan nyeri punggung bawah kronis dibandingkan dengan nyeri punggung bawah akut, yang mungkin disebabkan karena individu yang memiliki nyeri punggung bawah kronis memiliki kewaspadaan lebih tinggi untuk memindahkan posisi duduk agar tidak merasakan rasa sakit dibandingkan dengan mereka yang tidak memiliki nyeri punggung bawah kronis. Akan tetapi hasil penelitian ini menunjukan bahwa nyeri punggung bawah bersifat multifaktorial sehingga bisa saja ada faktor lain yang mempengaruhi nyeri punggung bawah selain gaya hidup sedenter, lama duduk, dan faktor-faktor lainnya.

Penelitian yang dilakukan oleh Dunk dkk (35) bertujuan untuk membandingkan respon postural dan tingkat rasa nyeri pada penderita nyeri punggung bawah dengan non-penderita nyeri punggung bawah saat duduk lama untuk memahami faktor biomekanikal yang mungkin berhubungan dengan duduk yang menyebabkan rasa nyeri punggung bawah. Penelitian dilakukan di Universitas Waterloo Kanada menggunakan desain studi prospektif dan berhasil mendapatkan tiga puluh dua partisipan yang diambil dari komunitas setempat terdiri dari delapan lakilaki non-penderita dan delapan perempuan non-penderita tanpa riwayat nyeri punggung bawah selama dua belas 
bulan terakhir dan sisanya adalah penderita sitting induced low back pain dengan jenis kelamin sama rata. Kriteria inklusi untuk penderita adalah memiliki riwayat nyeri punggung bawah tidak spesifik namun tidak menyebabkan disabilitas selama dua sampai dua puluh empat bulan terakhir yang dipicu oleh duduk, tidak dalam masa perawatan medis, baru saja menjalani operasi, tidak ada defisit neurologis dan tidak ada kelainan tulang belakang. Partisipan lalu dipasangkan dengan Tri-axial accelerometer untuk memonitor derajat tulang belakang selama 90 menit bekerja di depan komputer. Perubahan derajat tulang belakang dibedakan menjadi dua kategori yaitu berubah posisi (perubahan posisi tulang belakang lebih dari 5 derajat) dan gelisah (berubah posisi sedikit lalu kembali lagi ke posisi semula). Hasil penelitian menunjukan bahwa grup dengan nyeri tulang belakang merasakan peningkatan yang signifikan pada rasa nyeri $(\mathrm{p}<0.0001)$ sedangkan grup yang tidak memiliki nyeri punggung bawah hanya merasakan nyeri sedikit bahkan tidak nyeri sama sekali. Rata-rata setiap partisipan gelisah setiap 40-50 detik tetapi hanya penderita nyeri punggung bawah yang mendemonstrasikan peningkatan signifikan $(\mathrm{p}=0.04)$ dalam jumlah perubahan posisi selama 90 menit duduk; grup penderita berubah posisi setiap 4 menit selama 30 menit dibandingkan dengan grup non-penderita yang hanya berubah setiap 10 menit. Penderita nyeri punggung bawah juga memiliki derajat perubahan posisi lebih besar dan lebih sering merasa gelisah. Penderita nyeri punggung bawah mengalami peningkatan rasa nyeri yang lebih tinggi daripada non-penderita saat duduk lama dan pergerakan yang lebar dan sering tidak membantu dan mengurangi rasa nyeri pada penderita nyeri punggung bawah. Hasil ini juga sejalan dengan penelitian yang dilakukan Bontrup dkk (34) di mana penderita akan memiliki posisi duduk yang lebih statis dikarenakan perubahan posisi tidak membantu dan mengurangi rasa nyeri akibat duduk terlalu lama.

Studi yang dilakukan oleh Zemp dkk (36) bertujuan untuk menganalisa pengaruh nyeri punggung bawah pada perilaku duduk di lingkungan kantor. Studi berlokasi di Swiss dan dilakukan penelitian dengan desain studi prospektif terhadap dua puluh pekerja kantor yang terdiri dari tujuh perempuan dan sisanya laki-laki dengan rentang umur 27-57 tahun, dari partisipan tersebut berhasil didapatkan data dua puluh perilaku duduk saat bekerja menggunakan textile pressure mat (64 sensor matrix) yang diletakan di atas tempat duduk kerja partisipan. Partisipan juga diminta mengisi kuesioner yang sudah distandarisasi $(37,38)$ untuk menilai nyeri punggung bawah jangka pendek dan panjang untuk membagi partisipan menjadi dua grup (nyeri punggung bawah, tidak nyeri punggung bawah). Hasil Independent t-test menunjukan bahwa subjek yang memiliki nyeri punggung bawah dalam 24 jam terakhir memperlihatkan tren yang jelas pada pola perilaku duduk yang lebih statis. Ini sejalan dengan hasil penelitian Bontrup dkk (34) bahwa individu yang memiliki riwayat nyeri punggung bawah memiliki pola perilaku duduk statis yang disebabkan kewaspadaan tinggi terhadap perubahan posisi duduk yang menimbulkan rasa sakit, ini berarti perubahan posisi duduk juga tidak membantu mengurangi nyeri (35) akan tetapi perlu disadari bahwa pergerakan saat duduk juga diperlukan untuk melancarkan penyerapan nutrisi pada cincin tulang belakang, mengurangi tekanan berlebih pada cincin tulang belakang, dan membantu melancarkan peredaran darah dari dan ke otot (39-42).

\section{Faktor Risiko Lainnya}

Penelitian oleh Hanna dkk (53) berupaya untuk mencari tahu hubungan antara gaya hidup sedenter serta faktor psikososial dengan kejadian nyeri punggung, baik nyeri punggung bawah ataupun nyeri punggung atas, pada pekerja akademik dan non-akademik di Universitas Qatar. Studi ini merupakan studi cross-sectional yang menggunakan istrumen kuesioner berupa IPAQ (International Physical Activity Questionnaire) dan GPAQ (Global Physical Activity Questionnaire) serta ALBPSQ (Acute Low Back Pain Screening Questionnaire) untuk mengumpulkan data dari 479 partisipan yang berusia 25 tahun ke atas. Partisipan diminta untuk mengisi kuesioner mengenai kesehatan dan kesejahteraan (well-being) yang mencakup informasi tentang waktu duduk sebagai ukuran perilaku hidup sedenter, aktivitas fisik, nyeri punggung dan kesejahteraan. Hasil studi menunjukkan bahwa sebagian besar partisipan yang bekerja kantor mengalami lebih banyak nyeri punggung bawah. Perempuan lebih banyak melaporkan kejadian nyeri punggung daripada pria, kemungkinan karena staff non-akademik didominasi oleh perempuan. Hal ini sejalan dengan penelitian sebelumnya yang menyatakan bahwa jenis kelamin perempuan merupakan faktor risiko (52). Aktivitas fisik yang tinggi (vigorous physical activity) merupakan faktor protektif terhadap individual yang mengalami nyeri punggung bawah, oleh karena individu dengan nyeri punggung bawah jarang melaporkan aktivitas fisik. Perilaku sedenter atau duduk terlalu lama berasosiasi secara signifikan dengan nyeri punggung bawah maupun atas, dimana perilaku duduk lebih dari 2 jam ketika bekerja dan penggunaan komputer yang sering dan berlebih akan meningkatkan peluang kejadian nyeri punggung. Semua individu yang melaporkan nyeri punggung memiliki suasana hati yang cenderung depresif. Sehingga dapat dikonklusikan bahwa kejadian nyeri punggung tidak hanya disebabkan oleh duduk lama saja, tetapi juga dipengaruhi oleh faktor psikososial seperti suasana hati yang dipengaruhi oleh faktor di lingkungan kerja atau lingkungan sosial.

Studi oleh Citko dkk (10) di Polandia menemukan bahwa gaya hidup sedenter pada 609 perawat dan paramedik berusia 30-60 tahun berpengaruh secara siginifikan terhadap peningkatan kejadian nyeri punggung bawah berulang dan peningkatan aktivitas fisik berpengaruh signifikan terhadap nyeri punggung bawah yang kronis. Kondisi-kondisi yang diklasifikasikan sebagai sindrom metabolik dalam kelompok bergaya hidup sedenter dapat meningkatkan peluang terjadinya nyeri punggung bawah yang tidak spesifik secara siginifikan. Kondisi-kondisi 
ini mencakup tekanan darah tinggi, diabetes tipe 2, dan hiperlipidemi. Dalam studi ini, ditemukan bahwa gaya hidup sedenter dapat meningkatkan risiko nyeri punggung berulang sebesar lebih dari 3.5 kali dan peluang terjadinya nyeri punggung kronis dapat meningkat hingga lebih dari 10 kali pada kelompok dengan aktivitas fisik yang tinggi. Hasil studi ini mengkonfirmasi hipotesis bahwa hubungan antara tingkat keaktifan fisik dan nyeri punggung bawah yang tidak spesifik, dapat berupa kurva dalam bentuk $U$; yang berarti aktivitas fisik yang kurang dan aktivitas fisik yang berlebih (aktivitas yang tidak sehat), dapat meningkatkan risiko nyeri punggung (54). Namun, hasil penemuan ini bertentangan dengan penelitian yang dilakukan oleh Hanna dkk (53) yang menyatakan bahwa aktivitas fisik yang tinggi merupakan faktor protektif terhadap kejadian nyeri punggung. Oleh karena itu, hasil studi ini penting dan bersifat kontradiktif terhadap anggapan bahwa aktivitas fisik yang lebih tinggi berarti lebih baik dan menurunkan risiko nyeri punggung bawah, sehingga penting untuk dipelajari lebih lanjut agar dapat memberikan edukasi yang sesuai kepada masyarakat.

\section{Pembahasan Hasil Penelusuran Literatur}

Studi mengenai hubungan nyeri punggung bawah dengan lamanya duduk dan hasilnya masih menimbulkan kontroversi $(31,32)$. Terdapat penelitian yang menemukan bahwa lama duduk berhubungan erat dengan kejadian nyeri punggung bawah (16-24) namun terdapat juga penelitian yang tidak menemukan bahwa lama duduk berhubungan erat atau memiliki pengaruh signifikan dengan kejadian nyeri punggung bawah (27-30). Kontradiksi ini mungkin terjadi karena tingginya tingkat bias dalam studi terutama pada studi yang bersifat subjektif, dimana para pesertanya melaporkan sendiri lama waktu duduk mereka sebagai tolak ukur hubungan duduk lama dengan nyeri punggung bawah $(20,55)$. Pengukuran gaya hidup sedenter dan lama waktu duduk yang dilakukan sendiri oleh para peserta memiliki tingkat bias yang lebih tinggi jika dibandingkan lama waktu duduk yang diukur secara objektif oleh peneliti (56-58). Alasan lain yang mungkin menjadi penyebab kontradiksi ini adalah terdapat banyaknya studi yang dilakukan terhadap populasi yang heterogen dalam hal status sosial-ekonomi, sehingga meningkatkan risiko perancu residual dari sisi status sosial-ekonomi (59-61).

Setelah melakukan studi literatur dapat disimpulkan bahwa kausal nyeri punggung bawah bersifat multifaktorial $(34,53)$ dan setiap faktor risiko tidak dapat berperan tunggal. Misalnya dalam faktor risiko duduk lama akan dibarengi oleh posisi duduk statis $(34,36)$, dipengaruhi faktor psikososial (53), serta jenis kelamin di mana perempuan lebih banyak melaporkan rasa nyeri punggung bawah $(32,52)$. Kendati demikian, satu studi yang dilakukan terhadap kohort pekerja kerah biru menunjukkan bahwa waktu duduk yang lebih lama dapat menjadi faktor pelindung dari nyeri punggung bawah (47). Efek menguntungkan ini dapat diraih karena para pekerja kerah biru seringkali melakukan aktivitas yang juga menjadi faktor risiko nyeri punggung bawah seperti berdiri terlalu lama serta mengangkat dan membawa barang $(3,47)$. Sehingga waktu duduk yang lebih lama akan memberikan perlindungan terhadap nyeri punggung bawah karena waktu duduk dipergunakan untuk mengistirahatkan diri dari aktivitas penanganan manual material tersebut.

Namun yang pasti, duduk terlalu lama menyebabkan kegelisahan dan rasa tidak nyaman pada punggung bawah dan akan mengakibatkan penderita melakukan pergeseran dan perubahan postur duduk lebih sering (43). Hal ini dikarenakan posisi duduk statis dalam waktu lama akan memberikan tekanan pada cincin tulang belakang sehingga dapat mengganggu proses penyerapan nutrisi, peredaran darah, dan akhirnya menimbulkan kelelahan dan kesakitan pada otot punggung $(36,39)$. Oleh karena itu, disarankan untuk membiasakan diri melakukan peregangan saat duduk dan istirahat sejenak daripada melakukan pergeseran atau penggantian postur duduk yang dianggap kurang efektif dalam mengatasi rasa nyeri pada punggung bawah ketika duduk lama (35).

\section{Kesimpulan dan Saran}

Hubungan nyeri punggung bawah dengan duduk lama masih belum dapat digambarkan secara pasti dan masih menimbulkan perdebatan. Terdapat berbagai penelitian dengan hasil pro dan kontra, sehingga tidak dapat dipastikan ada atau tidaknya hubungan kausalitas antara duduk lama dengan nyeri punggung bawah. Penyebab dari nyeri punggung bawah bersifat multifaktorial, dengan berbagai faktor risiko seperti duduk lama, perilaku duduk yang statis, umur, jenis kelamin, psikososial, gaya hidup, aktivitas fisik, dan lain sebagainya Tinjauan literatur sistematis yang lebih terstruktur dengan mengikuti panduan standar internasional untuk menghasilkan tinjauan dengan informasi yang lebih lengkap, detil dan komprehensif mengenai hubungan duduk lama dengan nyeri punggung bawah berdasarkan studi termutakhir diperlukan. Penulis juga memiliki opini bahwa penyebab adanya pro dan kontra dalam studi mengenai hubungan nyeri punggung bawah dengan duduk lama juga disebabkan oleh masih belum ada studi yang benar-benar bersifat objektif dalam meneliti hubungan keduanya di mana dalam studi yang ada pelaporan rasa nyeri dan sakit pada punggung bawah masih menggunakan kuesioner atau jawaban dari responden yang memiliki bias yang cukup tinggi sedangkan studi objektif yang ada meneliti hubungan keduanya dalam waktu yang singkat dan condong pada penelitian mengenai hubungan antara nyeri 
punggung bawah dengan posisi duduk saat duduk lama. Penelitian objektif dalam waktu yang panjang seperti kohort diperlukan untuk meneliti apakah kebiasaan duduk lama dalam jangka waktu panjang dapat menyebabkan munculnya nyeri punggung bawah walaupun memang penelitian jenis ini membutuhkan usaha dan sumber daya yang cukup besar untuk merealisasikannya.

\section{Daftar Pustaka}

1. Krismer M, van Tulder M, Low Back Pain Group of the Bone and Joint Health Strategies for Europe Project. Strategies for prevention and management of musculoskeletal conditions. Low back pain (nonspecific). Best Pract Res Clin Rheumatol. 2007;

2. Hoy D, March L, Brooks P, Blyth F, Woolf A, Bain C, et al. The global burden of low back pain: Estimates from the Global Burden of Disease 2010 study. Ann Rheum Dis. 2014;

3. Violante FS, Mattioli S, Bonfiglioli R. Low-back pain. In: Handbook of Clinical Neurology. 2015.

4. Spittaels H, Van Cauwenberghe E, Verbestel V, De Meester F, Van Dyck D, Verloigne M, et al. Objectively measured sedentary time and physical activity time across the lifespan: A cross-sectional study in four age groups. Int J Behav Nutr Phys Act. 2012;

5. Vandelanotte C, Duncan MJ, Short C, Rockloff M, Ronan K, Happell B, et al. Associations between occupational indicators and total, work-based and leisure-time sitting: A cross-sectional study. BMC Public Health. 2013;

6. Matthews CE, Chen KY, Freedson PS, Buchowski MS, Beech BM, Pate RR, et al. Amount of time spent in sedentary behaviors in the United States, 2003-2004. Am J Epidemiol. 2008;

7. Petersen CB, Bauman A, Grønbæk M, Helge JW, Thygesen LC, Tolstrup JS. Total sitting time and risk of myocardial infarction, coronary heart disease and all-cause mortality in a prospective cohort of Danish adults. Int J Behav Nutr Phys Act. 2014;

8. Bennie JA, Chau JY, van der Ploeg HP, Stamatakis E, Do A, Bauman A. The prevalence and correlates of sitting in European adults - a comparison of 32 Eurobarometer-participating countries. Int J Behav Nutr Phys Act. 2013;

9. Bo Andersen L, Wedderkopp N, Leboeuf-Yde C. Association between back pain and physical fitness in adolescents. Spine (Phila Pa 1976). 2006;

10. Citko A, Górski S, Marcinowicz L, Górska A. Sedentary lifestyle and nonspecific low back pain in medical personnel in North-East Poland. Biomed Res Int. 2018;2018.

11. Pope MH, Goh KL, Magnusson ML. Spine ergonomics. Annual Review of Biomedical Engineering. 2002.

12. Corlett EN. Background to sitting at work: Research-based requirements for the design of work seats. Ergonomics. 2006;

13. Nachemson AL. Disc pressure measurements. Spine (Phila Pa 1976). 1981;

14. Beach TAC, Parkinson RJ, Stothart JP, Callaghan JP. Effects of prolonged sitting on the passive flexion stiffness of the in vivo lumbar spine. Spine J. 2005 Mar;5(2):145-54.

15. Kong PW. Changes in perceived comfort, strength and electromyographic response in lower back, hip and leg muscles during 8-hour prolonged sitting. In: IFMBE Proceedings. 2010.

16. Omokhodion FO, Sanya AO. Risk factors for low back pain among office workers in Ibadan, Southwest Nigeria. Occup Med (Chic Ill). 2003;

17. Skov T, Borg V, Ørhede E. Psychosocial and physical risk factors for musculoskeletal disorders of the neck, shoulders, and lower back in salespeople. Occup Environ Med. 1996;

18. Spyropoulos P, Papathanasiou G, Georgoudis G, Chronopoulos E, Koutis H, Koumoutsou F. Prevalence of low back pain in Greek public office workers. Pain Physician. 2007;

19. Rotgoltz J, Derazne E, Froom P, Grushecky E, Ribak J. Prevalence of low back pain in employees of a pharmaceutical company. Isr J Med Sci. 1992;

20. Walsh K, Varnes N, Osmond C, Styles R, Coggon D. Occupational causes of low-back pain. Scand J Work Environ Heal. 1989;

21. Lee YH, Chiou WK. Risk factors for low back pain, and patient-handling capacity of nursing personnel. J Safety Res. 1994;

22. Krapac L, Sakic D. Locomotor strain syndrome in users of video display terminals. In: Arhiv za Higijenu Rada i Toksikologiju. 1994.

23. Yue P, Liu F, Li L. Neck/shoulder pain and low back pain among school teachers in China, prevalence and risk factors. BMC Public Health. 2012;

24. Sjolie AN. Persistence and change in nonspecific low back pain among adolescents: A 3-year prospective study. Spine (Phila Pa 1976). 2004;

25. Naqvi SA. Study of forward sloping seats for VDT workstations. J Hum Ergol (Tokyo). 1994; 
26. Winkel J, JØrgensen K. Swelling of the foot, its vascular volume and systemic hemoconcentration during long-term constrained sitting. Eur J Appl Physiol Occup Physiol. 1986;

27. Hartvigsen J, Leboeuf-Yde C, Lings S, Corder EH. Review Article: Is sitting-while-at-work associated with low back pain? A systematic, critical literature review. Scandinavian Journal of Public Health. 2000.

28. Roffey DM, Wai EK, Bishop P, Kwon BK, Dagenais S. Causal assessment of occupational sitting and low back pain: results of a systematic review. Spine Journal. 2010.

29. Kwon BK, Roffey DM, Bishop PB, Dagenais S, Wai EK. Systematic review: Occupational physical activity and low back pain. Occupational Medicine. 2011.

30. Lis AM, Black KM, Korn H, Nordin M. Association between sitting and occupational LBP. European Spine Journal. 2007.

31. Gupta N, Christiansen CS, Hallman DM, Korshøj M, Carneiro IG, Holtermann A. Is objectively measured sitting time associated with low back pain? A cross-sectional investigation in the NOMAD study. PLoS One. 2015;10(3):1-18.

32. Nordin NAM, Singh DKA, Kanglun L. Low back pain and associated risk factors among health science undergraduates. Sains Malaysiana. 2014 Mar;43(3):423-8.

33. Nyland LJ, Grimmer KA. Is undergraduate physiotherapy study a risk factor for low back pain? A prevalence study of LBP in physiotherapy students. BMC Musculoskelet Disord. 2003;

34. Bontrup C, Taylor WR, Fliesser M, Visscher R, Green T, Wippert PM, et al. Low back pain and its relationship with sitting behaviour among sedentary office workers. Appl Ergon. 2019 Nov 1;81.

35. Dunk NM, Callaghan JP. Lumbar spine movement patterns during prolonged sitting differentiate low back pain developers from matched asymptomatic controls. Work. 2010;35(1):3-14.

36. Zemp R, Fliesser M, Wippert PM, Taylor WR, Lorenzetti S. Occupational sitting behaviour and its relationship with back pain - A pilot study. Appl Ergon [Internet]. 2016;56:84-91. Available from: http://dx.doi.org/10.1016/j.apergo.2016.03.007

37. Von Korff M. Assessment of chronic pain in epidemiological and health services research: Empirical bases and new directions. In: Handbook of pain assessment, 3rd ed. 2011.

38. Von Korff M, Ormel J, Keefe FJ, Dworkin SF. Grading the severity of chronic pain. Pain. 1992;

39. Adams MA, Hutton WC. The effect of posture on the fluid content of lumbar intervertebral discs. Spine (Phila Pa 1976). 1983;

40. Adams MA, Hutton WC. The effect of posture on diffusion into lumbar intervertebral discs. J Anat. 1986;

41. Adams MA, McMillan DW, Green TP, Dolan P. Sustained loading generates stress concentrations in lumbar intervertebral discs. Spine (Phila Pa 1976). 1996;

42. Solomonow M, Zhou BH, Baratta R V., Burger E. Biomechanics and electromyography of a cumulative lumbar disorder: Response to static flexion. Clin Biomech. 2003;

43. Waongenngarm P, van der Beek AJ, Akkarakittichoke N, Janwantanakul P. Perceived musculoskeletal discomfort and its association with postural shifts during 4-h prolonged sitting in office workers. Appl Ergon. 2020 Nov 1;89.

44. Nakphet N, Chaikumarn M, Janwantanakul P. Effect of different types of rest-break interventions on neck and shoulder muscle activity, perceived discomfort and productivity in symptomatic VDU operators: A randomized controlled trial. Int J Occup Saf Ergon. 2014;

45. Waongenngarm P, Rajaratnam BS, Janwantanakul P. Perceived body discomfort and trunk muscle activity in three prolonged sitting postures. J Phys Ther Sci. 2015;

46. Hägg G. Static work load and occupational myalgia - A new explanation model. In: Electromyographical kinesiology. 1991.

47. Korshøj M, Jørgensen MB, Hallman DM, Lagersted-Olsen J, Holtermann A, Gupta N. Prolonged sitting at work is associated with a favorable time course of low-back pain among blue-collar workers: A prospective study in the dphacto cohort. Scand J Work Environ Heal. 2018;44(5):530-8.

48. Lunde LK, Koch M, Knardahl S, Veiersted KB. Associations of objectively measured sitting and standing with low-back pain intensity: A 6-month follow-up of construction and healthcare workers. Scand J Work Environ Heal. 2017;

49. Cohen SP, Chen Y, Neufeld NJ. Sacroiliac joint pain: A comprehensive review of epidemiology, diagnosis and treatment. Expert Review of Neurotherapeutics. 2013.

50. Cohen SP. Sacroiliac joint pain: A comprehensive review of anatomy, diagnosis and treatment. Anesthesia and Analgesia. 2005.

51. Manchikanti L, Singh V, Falco FJE, Benyamin RM, Hirsch JA. Epidemiology of low back pain in Adults. Neuromodulation. 2014;

52. Siahaan YMT, Hartoyo V. Sacroiliac Joint Pain: A Study of Predisposing Factors in an Indonesian Hospital. Open Pain J. 2019 Feb 19;12(1):1-5.

53. Hanna F, Daas RN, El-Shareif TJ, Al-Marridi HH, Al-Rojoub ZM, Adegboye OA. The relationship between sedentary behavior, back pain, and psychosocial correlates among university employees. Front 
Public Heal. 2019;7(APR):1-7.

54. Heneweer H, Vanhees L, Picavet HSJ. Physical activity and low back pain: A U-shaped relation? Pain. 2009;

55. Damkot DK, Pope MH, Lord J, Frymoyer JW. The relationship between work history, work environment and low-back pain in men. Spine (Phila Pa 1976). 1984;

56. Clark BK, Thorp AA, A.h. Winkler E, Gardiner PA, Healy GN, Owen N, et al. Validity of self-reported measures of workplace sitting time and breaks in sitting time. Med Sci Sports Exerc. 2011;

57. Lagersted-Olsen J, Korshoj M, Skotte J, Carneiro IG, Sogaard K, Holtermann A. Comparison of objectively measured and self-reported time spent sitting. Int J Sports Med. 2014;

58. Affuso O, Stevens J, Catellier D, McMurray RG, Ward DS, Lytle L, et al. Validity of self-reported leisuretime sedentary behavior in adolescents. J Negat Results Biomed. 2011;

59. Xu Y, Bach E, Ørhede E. Work environment and low back pain: The influence of occupational activities. Occup Environ Med. 1997;

60. Macfarlane GJ, Thomas E, Papageorgiou AC, Croft PR, Jayson MIV, Silman AJ. Employment and physical work activities as predictors of future low back pain. Spine (Phila Pa 1976). 1997;

61. Jørgensen MB, Nabe-Nielsen K, Clausen T, Holtermann A. Independent effect of physical workload and childhood socioeconomic status on low back pain among health care workers in Denmark. Spine (Phila $\mathrm{Pa}$ 1976). 2013; 